Economics Development Analysis Journal

\title{
Economic Evaluation on the Application of Collaborative Forest Management (CFM)
}

\author{
Waridin $^{1 \bowtie}$, Rizky Karunia Dhea Safira ${ }^{2,}$ Indah Susilowati ${ }^{3}$, Kesi Wijajanti $^{4}$, Evi Yulia \\ Purwanti $^{5}$
}

1,2,3,5 Faculty of Economics and Business, Diponegoro University

${ }^{4}$ Faculty of Economics and Business, Semarang University

\begin{tabular}{|c|c|}
\hline Article Info & Abstract \\
\hline Hisrtory of Article & $\begin{array}{l}\text { This study aims to analyze the collaborative forest management as well as the economic benefits } \\
\text { obtained by forest village communities through intercropping of maize plants and cattle productive }\end{array}$ \\
\hline Received July 2019 & business. 80 respondents were selected through non probability sampling techniques with saturated \\
\hline Accepted September 2019 & sample methods. The research data was collected by conducting observations, in-depth interviews \\
\hline Pusblished November & and distributing questionnaires to respondents and key informants. The data obtained were analyzed \\
\hline 2019 & $\begin{array}{l}\text { using descriptive analysis with quantitative methods consisting of income analysis, } \mathrm{R} / \mathrm{C} \text { ratio, co- } \\
\text { management analysis and stakeholder analysis and productive business of cattle. The results show } \\
\text { that the economic benefit of maize cropping obtained by Sumberejo village and Padaan Village has } \\
\text { given them profit with an } \mathrm{R} / \mathrm{C} \text { ratio of } 1.4 \text { and } 1.7 \text {. For cattle productive business, Sumberejo Village }\end{array}$ \\
\hline $\begin{array}{l}\text { Keywords: } \\
\text { Blora, Co management, } \\
\text { Income, Social-forest, } \\
\text { Stakeholders }\end{array}$ & $\begin{array}{l}\text { has gotten a profit with the } \mathrm{R} / \mathrm{C} \text { ratio over the total cost of } 1.07 \text { and Padaan Village has an } \mathrm{R} / \mathrm{C} \text { ratio } \\
\text { of } 1.00 \text { (Break Even Point). Through the Mann Whitney statistical test there are differences in } \\
\text { income between the sharing forest village (Sumberejo Village) and the non-sharing forest village } \\
\text { (Padaan Village). Cattle productive businesses are found to have no difference in income values. } \\
\text { Collaborative based forest management at the research location through the concept of co } \\
\text { management analysis showed good results with a total score of } 3.5 \text { (close to } 4 \text { ). A co management } \\
\text { approach is needed for better future forest management. }\end{array}$ \\
\hline
\end{tabular}

(C) 2019 Universitas Negeri Semarang

Corresponding author:

Address: : Prof. H. Soedarto, S.H. - Tembalang Semarang,

ISSN 2252-6560

Central Java, Indonesia

E-mail: waridin.dr@gmail.com 


\section{INTRODUCTION}

Indonesia is a country with the 9th largest forest area in the world. Therefore, Indonesia's forests are very beneficial in supporting the productivity in agricultural sector. As what is stated in the Act No. 41 year 1999 that due to the wide forest area, the use of forest is focused on benefiting the people. Therefore, forest management and utilization in Indonesia needs to be carried out effectively and efficiently. Figure 1 shows the ranking of Indonesia's forests in the world in 2015. Since nearly $70 \%$ of Indonesia's land consists of forest areas, the risk of deforestation becomes really high. Up to now, deforestation is still one of Indonesia's unsolved issues. In 2010-2015 there were 684 thousand forest areas lost each year. This is not only caused by natural factors, but also due to the existence of centralized forest management which causes overexploitation of forest areas. Therefore, the forests lose their roles as a source of food, prevention of natural disasters, to fulfill housing needs for the collaborative. Deforestation also occurs in Java, where the island has the third largest forest area after Sumatera and Kalimantan. Deforestation on Java Island occurs in 5,500 hectares of forest area (Agro Indonesia, 2018).

The centralized forest management supports a new paradigm in forest management in Java, namely Pengelolaan Hutan Bersama Masyarakat (CBFM) or Collaborative Forest Management by Perhutani. CBFM is intended to improve forest management and utilization by considering the welfare of the collaborative (Perhutani, 2001). The purpose of CFM is not only so that Perum Perhutani can gain as much profit as possible from the managed forests, but also to pay attention to the social and economic aspects of forest village communities (Tito, 2017). The successful realization of the CBFM objectives is inseparable from the participation of the collaborative around the forest (Damayantanti, 2011).

The Decree of the Board of Directors of Perum Perhutani Number 136 / KPTS / DIR/2001 concerning Forest Management (CBFM) encouraged Perhutani KPH Blora to cover 15,000 hectares of forest to implement the management system. The CBFM system was implemented in Sumberejo Village and Padaan Village, Japah District since 2003 as a village where most of the areas are forests. Activities from collaborative forest management are carried out with land use understanding plants. the people who live around the forest have gained economic benefits from intercropping of maize plants in forest land and the implementation of cattle productive business. In addition, economic benefits are obtained in the form of sharing funds for forest villages that have standing plants that are old enough to be harvested. Sumberejo Village specifically benefited from the wood sharing fund from the activity. CBFM implementation in Sumberejo and Padaan villages has provided economic benefits from year to year. However, due to lack of coordination between stakeholders and the low quality of human resources, the implementation of CBFM in both villages experienced a less than optimal development.

Collaboration between stakeholders involved between local government, nongovernmental organizations, academics, the private sector and other parties can encourage better management success (Ardiansyah et al, 2018). The approach to income and $R / C$ ratio analysis and co-management analysis have been widely used to calculate and analyze the benefits obtained from farming, knowing stakeholder collaboration in forest management, including the calculation of economic benefits obtained by Sumberejo and Padaan forest communities on CBFM programs.

Research on the same topic was carried out by Sari (2016) who calculated and analyzed the economic benefits of rice farming obtained by forest village communities due to the CBFM program in Situraja KPH Village, Indramayu. Gunawan et al., (2012) examined the implementation of CBFM in Cepu $\mathrm{KPH}$, Kurniawati (2015) which examined the application of co management in the management of wood sharing funds. Susilowati (2001) also examined the prospect of successful co-management in the prohibited fish system in West Sumatra. 


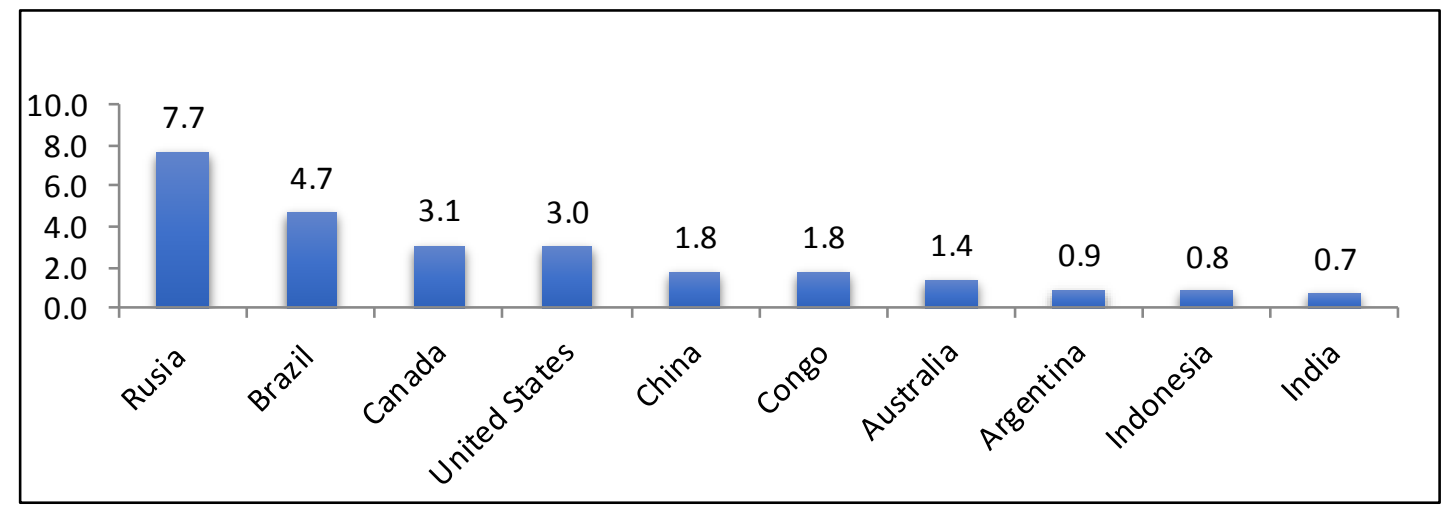

Figure. 1 Countries with Highest Forest Area (2015)

Kadir et al. (2013) which examined the collaboration of the management of Bantimurung National Park in South Sulawesi.

The purposes of this study are: 1) to estimate and compare the economic benefits obtained by the collaborative in forest villages that receive sharing funds to the collaborative in forest villages that do not receive sharing funds. 2) to analyze the forest management in both villages. The benefit of this research which is conducted in Blora, a regency that has the largest forest area, is that it can be used as a reference for further researches.

\section{RESEARCH METHODS}

Sumberejo Village and Padaan Village, Japah Subdistrict, Blora Regency, Central Java, were chosen as research locations because the two villages had implemented a Collaborative Based Forest Management (CBFM) program. The analytical method used in this study is quantitative analysis. This method is explained using a descriptive statistical approach to explain the profile of respondents, analysis of income and $\mathrm{R} /$ $\mathrm{C}$ ratios, co management analysis, and stakeholder analysis with in-depth interviews with key-figures (Perum Perhutani KPH Blora, BPH, Agriculture and Food Security, villages, sub-districts, pesanggem, NGOs, LMDH, academics, and entrepreneurs of meubel-teak) about CBFM.In general, the calculation of economic benefits is intended to find out the benefits generated by a resource economically.

The method used to describe the economic benefits obtained from the CBFM program in the forest village that receives sharing funds and that does not receive sharing funds is the analysis of income and $\mathrm{R} / \mathrm{C}$ ratios of maize cropping and cattle productive business. Mann Whitney statistical difference test is also used to determine the difference in income generated from the business. The assessment of 11 key conditions in accordance with Susilowati (2001) research and the results of the assessment from in-depth interviews were used to determine collaboration in forest management in the research area. Those 11 key conditions include 1) Clear boundaries, 2) Membership needs to be determined, 3) Group cohesion, 4) Existing organizations, 5) Benefits exceeding costs, 6) Participation from influential people, 7) Enforcement of management rules , 8) Legal rights to organize 9) Cooperation and leadership at the community level, 10) Decentralization and delegation of authority 11) Coordination between the government and the community. The assessment of those $11 \mathrm{key}$ conditions uses the Linkert 1-5 scale.

A stakeholder analysis is used to describe the importance and influence of each stakeholder involved in CBFM activities. Stakeholder analysis is carried out by identifying, classifying stakeholders and then evaluating interests, stakeholder influences with rating scales of 0 (not 
important) to 4 (very important). Identify stakeholders in four quadrants based on their interests and influences which include key players, context setter, subject and crowd (Reed et al., 2009).

\section{RESULTS AND DISCUSSION}

Sumberejo Village and Padaan Village are located in Japah District, Blora Regency. Forest management in those villages is under the auspices of Perhutani KPH Blora. Based on data obtained from Blora $\mathrm{KPH}$ through the evaluation of forest resource potential in $2017,13,285.82$ hectares of the total forest areas are production forest areas, $1,606.50$ hectares are protected areas, and other uses of 212.67 hectares. The borders of the $\mathrm{KPH}$ Blora area are $\mathrm{KPH}$ Mantingan in the north, $\mathrm{KPH}$ Cepu in the east, KPH Purwodadi and KPH Pati in the west, $\mathrm{KPH}$ Randublatung in the south.

Table 1 Socio-Economic Characteristics of Respondents in Sumberejo Village and Padaan Village,

\begin{tabular}{|c|c|c|c|c|c|c|c|}
\hline \multirow{2}{*}{\multicolumn{2}{|c|}{$\begin{array}{l}\text { Respondent } \\
\text { Characteristics }\end{array}$}} & \multicolumn{3}{|c|}{ Padaan Village } & \multicolumn{3}{|c|}{ Sumberejo Village } \\
\hline & & Freq & $(\%)$ & Information & Freq & $(\%)$ & Information \\
\hline \multirow[t]{3}{*}{ Age } & $20-40$ & 8 & $20,0 \%$ & Mean : 49,5 & 2 & $5 \%$ & Mean : 53,6 \\
\hline & $41-60$ & 27 & $67,5 \%$ & Max : 70 & 31 & $77,50 \%$ & Max : 75 \\
\hline & $>60$ & 5 & $12,5 \%$ & Min : 31 & 7 & $17,50 \%$ & Min : 38 \\
\hline \multirow{5}{*}{$\begin{array}{l}\text { Education } \\
\text { Level }\end{array}$} & Not & 0 & $0 \%$ & Mean : 8,85 & 0 & 0 & Mean : 8,85 \\
\hline & graduating & & & & & & \\
\hline & $\mathrm{SD}$ & 16 & $40 \%$ & Max: 12 & 19 & $47,5 \%$ & Max: 12 \\
\hline & SMP & 10 & $35 \%$ & Min: 6 & 12 & $30 \%$ & Min: 6 \\
\hline & SMA & 14 & $25 \%$ & & 9 & $22,5 \%$ & \\
\hline \multirow{2}{*}{$\begin{array}{l}\text { Farming } \\
\text { Type }\end{array}$} & Monokultur & 40 & $100 \%$ & - & 40 & $100 \%$ & - \\
\hline & Multikultur & 0 & $0 \%$ & & 0 & 0 & \\
\hline \multirow{3}{*}{$\begin{array}{l}\text { Farming } \\
\text { Experience }\end{array}$} & $<20$ tahun & 19 & $47,50 \%$ & Mean: 18,9 & 5 & $12,50 \%$ & Mean :26,3 \\
\hline & 20-40 tahun & 21 & $52,50 \%$ & Max: 35 & 33 & $82,50 \%$ & Max: 45 \\
\hline & $>40$ tahun & 0 & 0.0 & Min: 5 & 2 & $5 \%$ & Min: 10 \\
\hline \multirow[t]{10}{*}{ Land area } & 0,2 & 2 & $5,0 \%$ & & & & \\
\hline & 0,25 & 2 & $5,0 \%$ & & 5 & $12,50 \%$ & \\
\hline & 0,30 & 5 & $12,5 \%$ & Mean: 0,5 & 3 & $7,50 \%$ & Mean: 0,49 \\
\hline & 0,4 & 2 & $5,0 \%$ & Max: 2,0 & 3 & $7,50 \%$ & Max: 1 \\
\hline & 0,5 & 22 & $55,0 \%$ & Min: 0,3 & 22 & $55 \%$ & Min: 0,25 \\
\hline & 0,6 & & & & 1 & $2,50 \%$ & \\
\hline & 0,75 & & & & 5 & $12,50 \%$ & \\
\hline & 0,8 & 3 & $7,5 \%$ & & & & \\
\hline & 1,0 & 3 & $7,5 \%$ & & 1 & $2,50 \%$ & \\
\hline & 2,0 & 1 & $2,5 \%$ & & & & \\
\hline
\end{tabular}

Source: Processed Primary Data (2018), $N=80$ 
The forest area in the Perum Perhutani KPH Blora working area of the is managed by dividing the working area into 3 Forest Parts (BH), $6 \mathrm{BKPH}$, and $17 \mathrm{RPH}$. Each $\mathrm{RPH}$ and $\mathrm{BKPH}$ has various tasks ranging from planting, maintaining, monitoring, assisting / assisting extension agents to logging. Sumberejo Village is under BKPH (Forest Stakeholder Unit Section) Nglawungan with an area of 2,843.2 hectares. Whereas Padaan Village is under BKPH Ngapus with an area of 2,970.6 hectares. Administratively, Sumberejo Village is bordered by Padaan Village in the South. A summary of the socio-economic characteristics of the respondents of the two villages is presented in Table 1.
The respondents are those who joined as pesanggem who receive maize field assistance from Perum Perhutani in CBFM program. The number of respondents in this study are 40 people from each village. People in both villages have an average age of $41-60$ years. More than $50 \%$ of the pesanggem in the two villages have education equivalent to Elementary School (SD). All parties in both villages do monoculture farming. The average farming experience of each village ranges from 20 40 years. The average land area owned by pesanggem in the two villages is almost the same, namely 0.5 hectare.

Table 2 Income Analysis and R/C Ratio of Maize Farming in Sumberejo Village and Padaan

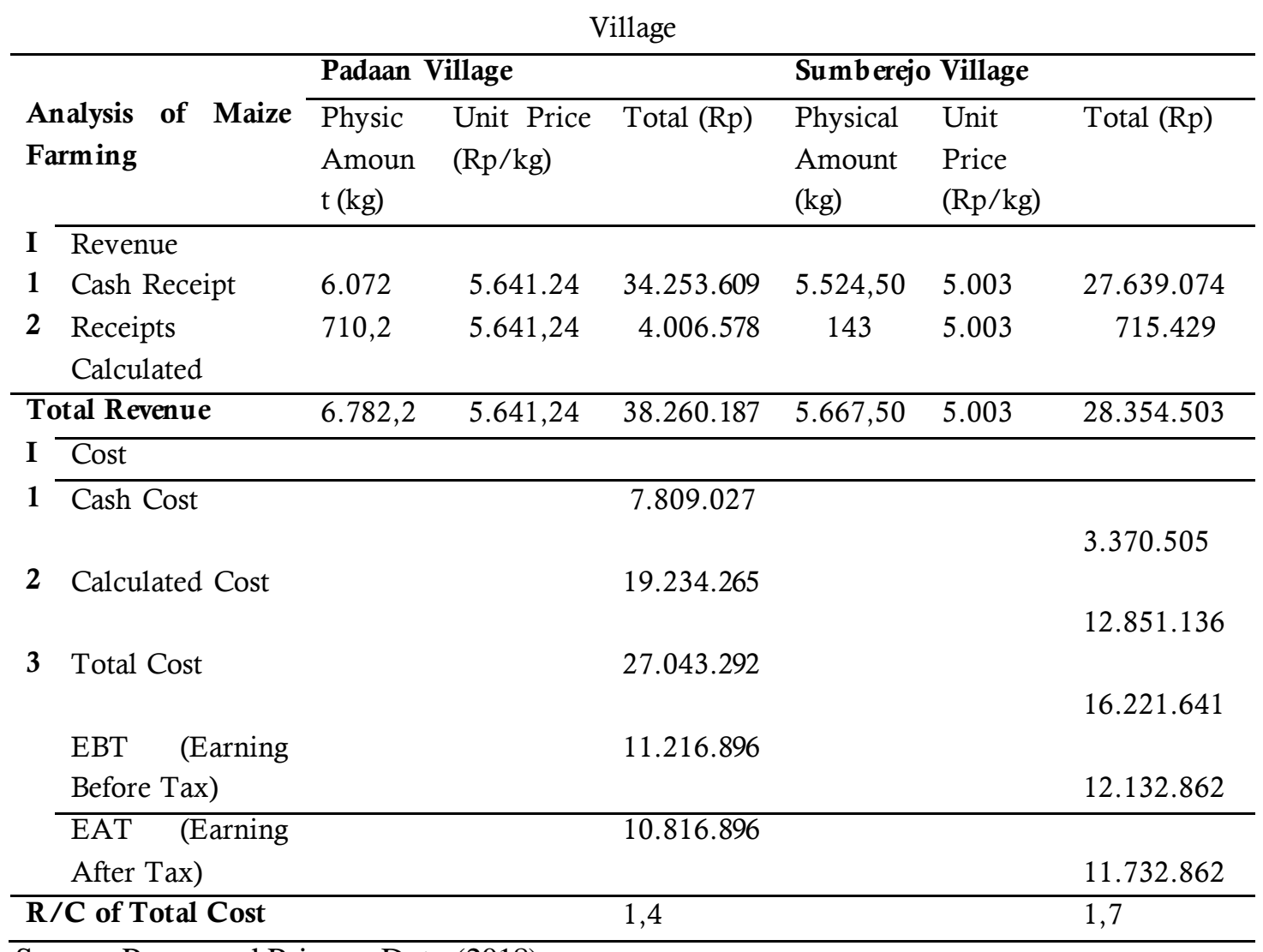

Source: Processed Primary Data (2018)

Analysis of Revenue and Cost Ratio (R/C) of Maize Farming and Cattle Productive Businesses, Maize farming income is obtained from the multiplication of corn production with the production price per kilogram, then deducted by the amount of costs incurred. The cost of producing corn farming includes cash costs and calculated costs. Cash costs include seeds, inorganic fertilizers, pesticides, out-of-family labor (TKLK), tractor rental, and transportation costs. The calculated costs include depreciation costs, labor in the family (TKDK), and organic 
fertilizer. The results of the analysis of CBFM economic benefits in the form of maize farming show that income in both forest villages after reduced by Sumberejo Village tax is IDR $10,816,896$ / MT and Padaan Village is IDR $11,732,862$ / MT (Table 2). Maize farming in both villages provides benefits. This is indicated by the
$\mathrm{R} / \mathrm{C}$ ratio of Padaan Village amounting to 1.4 and Sumberejo Village 1.7. A value of $\mathrm{R} / \mathrm{C}$ ratio of more than 1 is said that the business provides benefits (Nahak, 2018). Analysis of income and $\mathrm{R} / \mathrm{C}$ ratio of corn farming are described in Table 2

Table 3. Analysis of Revenue and R/C Cattle Productive Business Ratio of Sumberejo Village and Padaan Village.

\begin{tabular}{|c|c|c|c|c|c|c|}
\hline \multirow[b]{2}{*}{$\begin{array}{ll}\text { Analysis of } & \text { Cattle } \\
\text { Productive } & \text { Business }\end{array}$} & \multicolumn{3}{|c|}{ Desa Padaan } & \multicolumn{3}{|c|}{ Desa Sumberejo } \\
\hline & $\begin{array}{l}\text { Physical } \\
\text { Amount } \\
(\mathrm{kg})\end{array}$ & $\begin{array}{l}\text { Unit Price } \\
(\mathrm{Rp} / \mathrm{kg})\end{array}$ & Total (Rp) & $\begin{array}{l}\text { Physical } \\
\text { Amount } \\
(\mathrm{kg})\end{array}$ & $\begin{array}{l}\text { Unit Price } \\
(\mathrm{Rp} / \mathrm{kg})\end{array}$ & Total (Rp) \\
\hline I Revenue & & & & & & \\
\hline 1 Cash Receipt & 1 & 16.364 .583 & 16.364 .583 & 1 & 14.878 .205 & 14.878 .205 \\
\hline 2 Receipts Calculated & 0 & - & - & 0 & - & - \\
\hline Total Income & $\begin{array}{l}\text { Total } \\
\text { Revenue }\end{array}$ & & 16.364 .583 & & & 14.878 .205 \\
\hline I Cost & & & & & & \\
\hline$1 \longdiv { \text { Cash Cost } }$ & & & 10.253 .252 & & & 10.141 .366 \\
\hline 2 Calculated Cost & & & 5.087 .680 & & & 4.678 .522 \\
\hline 3 Total Cost & & & 15.340 .932 & & & 14.819 .888 \\
\hline $\begin{array}{l}\text { EBT (Earning Before } \\
\text { Tax) }\end{array}$ & & & 1.023 .651 & & & 58.317 \\
\hline EAT (Earning After Tax) & & & 1.010 .220 & & & 34.367 \\
\hline R/C of Total Cost & & & 1,07 & & & 1,00 \\
\hline R/C of Cash Cost & & & 1,6 & & & 1,5 \\
\hline
\end{tabular}

Source: Processed Primary Data (2018)

The income of cattle productive business is derived from the average income of cattle in a year then reduced by the total cost. Cattle production costs consist of cash costs and calculated costs. Cash costs include livestock seedlings, vaccines, out-of-family labor (TKLK), electricity, and water. Costs are calculated including depreciation costs, family labor, and green feed..The results of the income analysis from CBFM activities show that the income for the total cost of the village after tax is Rp. 1,010,220 and Desa Sumberejo is Rp. 34,367. The value of $\mathrm{R} / \mathrm{C}$ ratio for the total productive cost of Desa Padaan cattle is 1.07, which means that the business is profitable. While the $\mathrm{R} / \mathrm{C}$ ratio for the total productive costs of the Padaan village cattle is 1.00 where the business experiences BEP. Analysis of income and R/C ratio of cattle productive business is presented in Table 3.Related to the income analysis and R / C ratios presented in Table 2 and Table 3, Mann Whitney statistical difference test is conducted to determine the differences in the income between the sharing forest village and the non-sharing forest village. Based on the hypothesis proposed on corn farming in both forest villages, the Mann Whitney Test shows the value of Asymp. Sig. (2-tailed) $<\alpha$ (0.05), which is $0.011<0.05$, meaning that there are differences in corn farming income between the sharing forest village and the non-sharing forest village. Cattle productive business shows the value of Asymp. Sig. (2-tailed) $>\alpha$ (0.05), which is $0.992>0.05$, which means that there is no 
difference in cattle productive businesses income between the sharing forest village sharing with the non-sharing forest village. Co-Management Analysis, Co management analysis is carried out by evaluating 11 key conditions of CollaborativeBased Forest Management in Sumberejo Village and Padaan Village, Japah District, Blora Regency (Susilowati et al., 2003) shown in Table 4

Table 4. Co-Management Analysis of Collaborative-Based Forest Management (CBFM) in Sumberejo Village and Padaan Village, Japah District.

\begin{tabular}{|c|c|c|}
\hline Key Condition & Circumstances & Evaluation ( 1 to 5 scale) \\
\hline \multirow[t]{3}{*}{$\begin{array}{l}\text { Clear } \\
\text { boundaries }\end{array}$} & $\begin{array}{l}\text { Managed areas have different physical boundaries in } \\
\text { order to be noticeable by people }\end{array}$ & \multirow{3}{*}{4,8} \\
\hline & $\begin{array}{l}\text { Communities can understand and observe boundaries } \\
\text { based on existing ecosystems }\end{array}$ & \\
\hline & $\begin{array}{l}\text { The community manages land in accordance with agreed } \\
\text { limits }\end{array}$ & \\
\hline \multirow{4}{*}{$\begin{array}{l}\text { Membership } \\
\text { needs to be } \\
\text { determined }\end{array}$} & Only people who are members of the LMDH have the & \multirow{4}{*}{3,7} \\
\hline & right to carry out forest management in restricted areas. & \\
\hline & $\begin{array}{l}\text { LMDH members and communities participate in forest } \\
\text { resource management }\end{array}$ & \\
\hline & $\begin{array}{l}\text { The number of LMDH members is not too large to avoid } \\
\text { the effectiveness of decision making }\end{array}$ & \\
\hline \multirow{4}{*}{$\begin{array}{l}\text { Group } \\
\text { Cohesion }\end{array}$} & The managed area is close to the Forest Village & \multirow{4}{*}{3,8} \\
\hline & Community group & \\
\hline & $\begin{array}{l}\text { High levels of homogeneity (kinship, ethnicity, religion, } \\
\text { habits, beliefs, ideology }\end{array}$ & \\
\hline & Understand problems, strategies and results & \\
\hline \multirow[t]{3}{*}{$\begin{array}{l}\text { Existing } \\
\text { Organization }\end{array}$} & $\begin{array}{l}\text { The Village Forest Community, both those who are } \\
\text { members of the LMDH and do not understand the } \\
\text { traditional community-based system }\end{array}$ & \multirow{3}{*}{3,4} \\
\hline & $\begin{array}{l}\text { The Village Forest community understands the existence } \\
\text { of the organization }\end{array}$ & \\
\hline & $\begin{array}{l}\text { Village Forest Communities (LMDH) as representatives } \\
\text { of stakeholders and resource users participating in forest } \\
\text { management. }\end{array}$ & \\
\hline \multirow[t]{3}{*}{$\begin{array}{l}\text { Benefits } \\
\text { exceeding cost }\end{array}$} & $\begin{array}{l}\text { Compliance with community-based management } \\
\text { exceeds the investment costs for activities }\end{array}$ & \multirow{3}{*}{3,3} \\
\hline & $\begin{array}{l}\text { There are expectations from individuals that come from } \\
\text { participation }\end{array}$ & \\
\hline & Individuals get profit greater than the capital issued. & \\
\hline \multirow{3}{*}{$\begin{array}{l}\text { Influential } \\
\text { participation } \\
\text { from people }\end{array}$} & $\begin{array}{l}\text { People who collect information about forestry also make } \\
\text { decisions about management arrangements }\end{array}$ & \multirow{3}{*}{2,9} \\
\hline & $\begin{array}{l}\text { Management arrangements mostly affect individuals who } \\
\text { make and change their settings. }\end{array}$ & \\
\hline & $\begin{array}{l}\text { Individuals understand and are affected by the rules that } \\
\text { are compiled. }\end{array}$ & \\
\hline \multirow{2}{*}{$\begin{array}{l}\text { Enforcement of } \\
\text { management } \\
\text { rules }\end{array}$} & $\begin{array}{l}\text { All Forest Village Communities can enforce laws and } \\
\text { regulations. }\end{array}$ & \multirow[t]{2}{*}{3,1} \\
\hline & The rules for managing forest resources are simple & \\
\hline
\end{tabular}


Waridin, et.al / Economics Development Analysis Journal 8 (4) (2019)

\begin{tabular}{|c|c|c|}
\hline Key Condition & Circumstances & Evaluation ( 1 to 5 scale) \\
\hline & $\begin{array}{l}\text { Forest village members and communities understand the } \\
\text { rules in theory and their application. }\end{array}$ & \\
\hline \multirow[t]{3}{*}{$\begin{array}{l}\text { Legal rights to } \\
\text { organize }\end{array}$} & $\begin{array}{l}\text { The government has regulations to determine and clarify } \\
\text { responsibilities and authorities }\end{array}$ & \multirow{3}{*}{3,6} \\
\hline & $\begin{array}{l}\text { Legal rights are owned by organizations / groups in } \\
\text { making and managing arrangements according to their } \\
\text { needs }\end{array}$ & \\
\hline & $\begin{array}{l}\text { Forest village communities or LMDH members apply } \\
\text { regulations / norms that exist in the implementation of } \\
\text { CFM. }\end{array}$ & \\
\hline \multirow{3}{*}{$\begin{array}{l}\text { Cooperation } \\
\text { and leadership } \\
\text { at the } \\
\text { community } \\
\text { level }\end{array}$} & $\begin{array}{l}\text { The community has the willingness and incentives to } \\
\text { participate (money, time, energy, money) in managing } \\
\text { fisheries resources }\end{array}$ & \multirow{3}{*}{3,4} \\
\hline & $\begin{array}{l}\text { In the management process there is a group of individuals } \\
\text { who have a responsibility in leadership }\end{array}$ & \\
\hline & $\begin{array}{l}\text { The most appropriate form of collaboration here is: } \\
\text { Implementation of coaching and training activities } \\
\text { Discussion }\end{array}$ & \\
\hline \multirow{4}{*}{$\begin{array}{l}\text { Decentralizatio } \\
\mathrm{n} \quad \text { and } \\
\text { delegation of } \\
\text { authority }\end{array}$} & The government has established policies / regulations for & \multirow{4}{*}{3,3} \\
\hline & decentralization of administrative functions & \\
\hline & $\begin{array}{l}\text { The delegation of responsibility } / \text { authority with a } \\
\text { partnership approach in forestry resource management. }\end{array}$ & \\
\hline & $\begin{array}{l}\text { The delegation of authority / responsibility is well } \\
\text { structured. }\end{array}$ & \\
\hline \multirow[t]{5}{*}{$\begin{array}{l}\text { Coordination } \\
\text { between the } \\
\text { government } \\
\text { and the } \\
\text { community }\end{array}$} & $\begin{array}{l}\text { Coordination in monitoring management arrangements, } \\
\text { conflict resolution, strengthening enforcement of } \\
\text { regulations by implementing a partnership approach, } \\
\text { coordination is carried out by: } \\
\text { Local government } \\
\text { Local People } \\
\text { Universities }\end{array}$ & \multirow[t]{3}{*}{3,1} \\
\hline & $\begin{array}{l}\text { The partnership approach will facilitate coordination } \\
\text { between stakeholders }\end{array}$ & \\
\hline & $\begin{array}{l}\text { The partnership approach facilitates management } \\
\text { monitoring and conflict resolution from various levels of } \\
\text { stakeholders }\end{array}$ & \\
\hline & Total Score & 38,5 \\
\hline & Average Score & 3,5 \\
\hline
\end{tabular}

Rating scale: (1) Strongly disagree (2) Disagree (3) Doubtful (4) Agree (5) Strongly agree.

(1) Very bad (2) Bad (3) Neutral (4) Good (5) Very Good.

The total score of the assessment of $11 \mathrm{key}$ conditions in Collaborative-Based Forest Management (CBFM) in Sumberejo Village and Padaan Village, Japah District, Blora District,
Central Java in Table 4 is 38.5. The average score is 3.5 , which is close to 4 on the Linkert scale. This implies that forest management with the community in Sumberejo Village and Padaan 
Village, Japah District, Blora Regency is good. This condition illustrates that the co management approach is a concept of forest management that is suitable for better PBHM implementation.

Stakeholder Analysis Stakeholder analysis is carried out with the aim of analyzing the level of importance and influence of each stakeholder in PBHM. Stakeholders involved in PBHM in Sumberejo and Padaan Villages consist of Perum Perhutani, Forest Management Center (BPH), Village Authority, Agriculture and Food Security (Dipertan), NGOs, Subdistrict Authority, Teak Meuble Entrepreneurs, pesanggem and academics. According to Reed et al (2009) the classification of stakeholders is differentiated into key-players, context setter, subject, and crowd. Figure 2 shows the mapping of stakeholders based on their dependence and influence.
Relations between stakeholders can be explained through classification which includes a quadrant 1 context setter where the relevant stakeholders have a low dependency relationship and high influence. Stakeholders who occupy this position are academics. Key-players 2 quadrant has a high dependency relationship and high influence. Stakeholders who occupy this position are Perum Perhutani, Village Authority, District Authority, Agriculture and Food Security (Dipertan), and the Forest Village Community Institute (LMDH). Quadrant 3 is occupied by NGOs and pesanggem who belong to the category of subject (subject) in which the relevant stakeholders have a high dependence but influence is low. Quadrant 4 (crowd) has BPH and teak meuble entrepreneurs where the relevant stakeholders have a low dependency relationship and low influence.

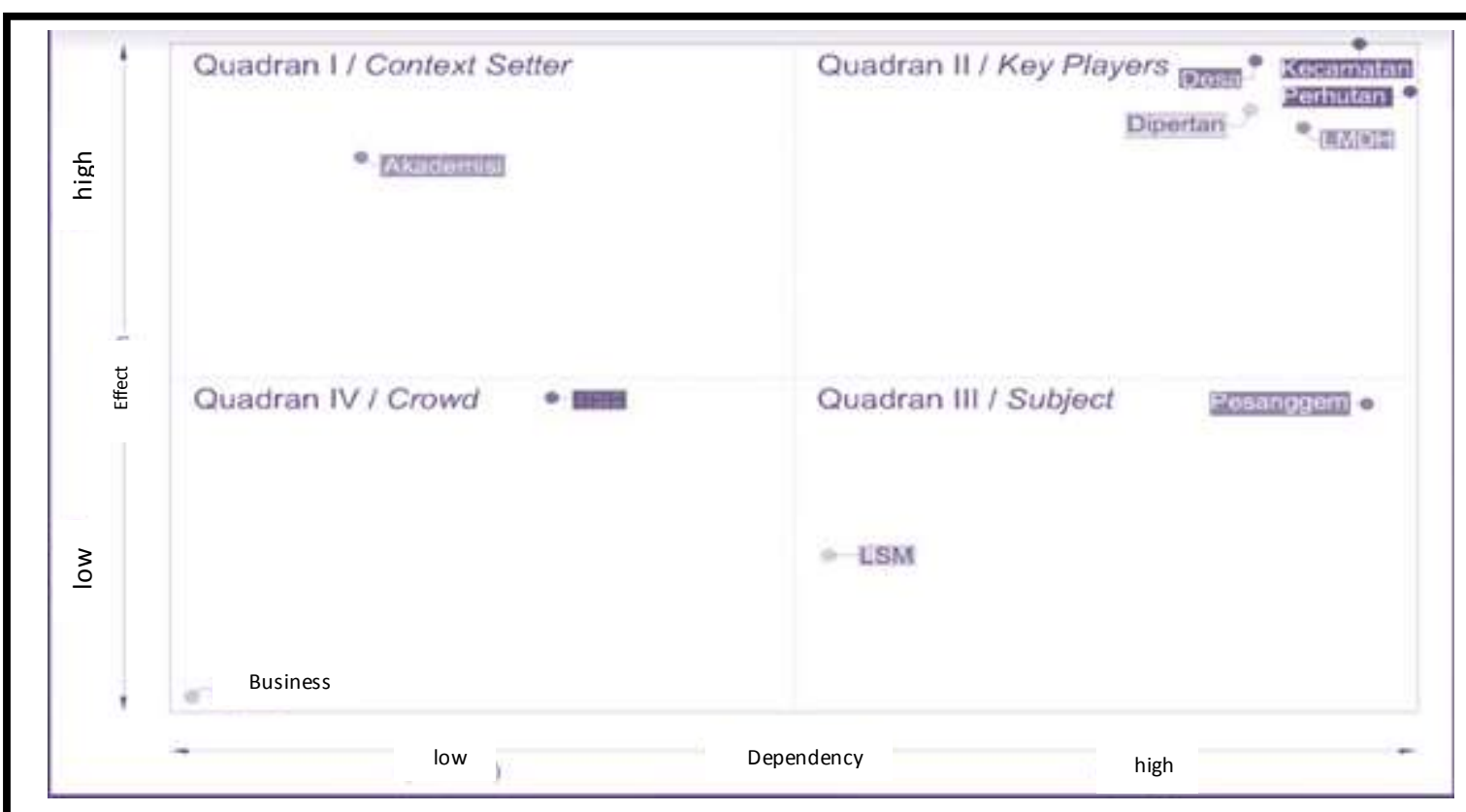

Fig. 1 Matrix of stakeholder mapping in Collaborative Forest Management

Figure 2 The Matrix of Stakeholder Mapping of CFM in the Sumberejo and Padaan Villages Source: Processed primary data (2018) 


\section{CONCLUSION}

CFM in Sumberejo Village and Padaan Village, Japah District, Blora Regency has provided economic benefits. It is proved by the CFM activities in the form of maize cropping and cattle productive business cattle that have provided benefits for the forest village community. Through analysis of co management and stakeholders, the collaborative forest management in Sumberejo and Padaan Villages is considered to be good. This is indicated by the total score of the assessment of the 11 key conditions of forest management with the community is 38.5 , where the average value is 3.5 which is close to 4 in the Linkert scale.

\section{REFERENCES}

Agroindonesia. (2018). Slowing Down, Indonesia Deforestation Period 2016-2017 Covering an Area of 479,000 hectares. Retrieved from http://agroindonesia.co.id/2018/01/ slowing-deforestation-indonesia- period-2016 2017-seluas-479-000-hektare /

Ardiansyah M., Suharno, Susilowati I (2019). Estimating the conservation value of mangrove forests in Marine Protected Areas: special reference to Karimunjawa waters, Indonesia. AACL Bioflux 12 (2): 437-447.

Damayantanti, P. T. (2011). Forest Conservation Efforts through Community Forest Management Resources. Community Journal, 3 (1), 70-82.

Gunawan, S. K., Barkey, R. A., \& H., M. A. I. (2012). Program Implementation of Forest Community Resource Management in Perspective Village Community Development in Blora Regency. Hassanudin University Publication Journal.

Kadir, W., W, A. K., Awang, S. A., Hadi, R., Maros, K., \& Regency, P. (2013). Analysis of Management of Bantimurung Bulusaraung National Park Management, South Sulawesi Province (Stakeholder Analysis of Bantimurung Bulusaraung National Park Management, South Sulawesi Province) Makassar Forestry Research Institute, South Sulawesi.

Kurniawati, \& Andry. (2015). Management of Timber Production Sharing Funds to Increase
Community Empowerment of Forest Villages (Study of the Application of Co-management in the Bersama Community Joint Forest Management System at Perum Perhutani Forest Management Unit of Cepu Forest Blora Regency). Journal of Public Administration, 3 (11), 1912-1916.

Nahak, M.H., \& Kune, S. J. (2018). Analysis of Maize Farming Income in Bannae Village, West Insana District, North Central Timor Regency. Agrimor, 2 (04), 55-56.

Perhutani. (2001). Decree of Perhutani Public Corporation Supervisory Board Number: 136 / Kpts / Dir / 2001. (10270).

Reed, M. S., Graves, A., Dandy, N., Posthumus, H., Hubacek, K., Morris, J., ... Stringer, L. C. (2009). Who's in and why? A typology of stakeholder analysis methods for natural resource management. Journal of Environmental Management, 90 (5), 19331949.

Sari, M. Y. (2016). Economic Evaluation of Community Forest Management in Situraja Village at Indramayu KPH. Bachelor Thesis 1 Department of Economic Resources and Environment Bogor Agricultural University. Bogor.

Susilowati, I. (2001). Prospect of Co-Management Approach in Managing Fisheries in Indonesia: Closer Look on Prohibited Fish Farming. Journal of Coastal Development, 5 (1), 41-45.

Susilowati, I., Budiati, L. (2003). An introduction of co-management approaches into Babon River management in Semarang, Central Java, Indonesia. Water Science and Technology. 48 (7), pp. 173-180.

Tito, M. (2017). Financial Analysis of Coffee Agroforestry under Mahogany and Pine Standards in the Community Forest Management Program (PHBM) at the Candiroto Forest Pemangkuan Resort. Faculty of Forestry. Electronic Theses and Disertation. Gadjah Mada University. 